\title{
Mass spectrometry imaging (MSI) of metals in mouse spinal cord by laser ablation ICP-MS
}

\author{
J. Sabine Becker, ${ }^{* a}$ Usarat Kumtabtim, ${ }^{a}$ Bei Wu, ${ }^{a}$ Petra Steinacker, ${ }^{b}$ \\ Markus Otto ${ }^{b}$ and Andreas Matusch ${ }^{c}$
}

Received 25th October 2011, Accepted 4th January 2012

DOI: $10.1039 / \mathrm{c} 2 \mathrm{mt00166g}$

Laser ablation inductively coupled plasma mass spectrometry (LA-ICP-MS) has been developed as a powerful MS imaging (MSI) tool for the direct investigation of element distributions in biological tissues. Here, this technique was adapted for the analysis of native mouse spinal cord cryosections of $3.1 \mathrm{~mm} \times 1.7 \mathrm{~mm}$ by implementing a new conventional ablation system (NWR-213) and improving the spatial resolution from $120 \mu \mathrm{m}$ to $65 \mu \mathrm{m}$ in routine mode. Element images of the spinal cord are provided for the first time and the metalloarchitecture was established using a multimodal atlas approach. Furthermore, the spatial distribution of $\mathrm{Rb}$ was mapped for the first time in biological tissue. Metal concentrations were quantified using matrix-matched laboratory standards and normalization of the respective ion intensities to the average ${ }^{13} \mathrm{C}$ ion intensity of standards and samples as a surrogate of slice thickness. The "butterfly" shape of the central spinal grey matter was visualized in positive contrast by the distributions of $\mathrm{Fe}, \mathrm{Mn}, \mathrm{Cu}$ and $\mathrm{Zn}$ and in negative contrast by $\mathrm{C}$ and $\mathrm{P} . \mathrm{Mg}, \mathrm{Na}, \mathrm{K}, \mathrm{S}$ and $\mathrm{Rb}$ showed a more homogenous distribution. The concentrations averaged throughout grey matter and white matter were 8 and $4 \mu \mathrm{g} \mathrm{g}^{-1}$ of $\mathrm{Fe}, 3$ and $2 \mu \mathrm{g} \mathrm{g}^{-1}$ of $\mathrm{Cu}, 8$ and $5 \mu \mathrm{g} \mathrm{g}^{-1}$ of $\mathrm{Zn}, 0.4$ and $0.2 \mu \mathrm{g} \mathrm{g}^{-1}$ of $\mathrm{Mn}$. The carbon concentration in white matter exceeded that of grey matter by a factor of 1.44. $\mathrm{Zn}$ and $\mathrm{Cu}$ at 9 and $4 \mu \mathrm{g} \mathrm{g}^{-1}$, respectively, were particularly enriched in the laminae I and II, in line with the high synaptic and cellular density there. Surprisingly $\mathrm{Zn}$ but not $\mathrm{Cu}$ was enriched in the central channel. $\mathrm{Rb}$ occurred at $0.3 \mu \mathrm{g} \mathrm{g}^{-1}$ with a distribution pattern congruent to that of $\mathrm{K}$. The coefficients of variation were $6 \%, 5 \%, 8 \%$ and $10 \%$ for $\mathrm{Fe}, \mathrm{Cu}, \mathrm{Zn}$ and $\mathrm{Mn}$, respectively, throughout three different animals measured on different days. These MSI analyses of healthy wild type spinal cords demonstrate the suitability of the established techniques for investigating diseased or transgenic states in future imaging studies.

\section{Introduction}

Rodent spinal cord has become an attractive subject of experimental neuroscience. A series of recent and ongoing studies has assessed pain, inflammatory or degenerative pathophysiology. ${ }^{1-3}$ Popular animal models which have been assessed in this scope were unilateral limb lesions, experimental autoimmune encephalomyelitis (EAE) or animals transgenic for proteins involved in redox and free radical metabolism. In several cases where the systemic central nervous system is affected the pathology of the spinal cord is most informative and the brain only a side scene.

\footnotetext{
${ }^{a}$ BrainMet Laboratory, Central Division of Analytical Chemistry, Forschungszentrum Jülich, D-52425 Jülich, Germany.

E-mail:s.becker@fz-juelich.de;Web:www.brainmet.com; Fax: 00492461612560

${ }^{b}$ Department of Neurology, University of Ulm, D-89075 Ulm, Germany

${ }^{c}$ NEMO Research Group, Department of Psychiatry, University of Bonn, D-53105 Bonn, Germany
}

Especially EAE which is the most common animal model for inflammatory disease preferentially affects the spinal cord.

As a major restriction, mouse spinal cord is largely not accessible by in vivo imaging techniques such as magnetic resonance tomography (MRT) or micro single photon or positron emission tomography (SPECT and PET). This is due to partial volume effects resulting from its small cross section, signal spillover from the surrounding ample plexus of blood vessels and magnetic field inhomogeneities arising from the bone channel. Therefore, spinal cord research essentially relies on ex vivo assessment. In addition to classical histochemical techniques this field is increasingly enriched by instrumental imaging techniques emerging from the disciplines of solid state research and analytical chemistry.

Bioimaging analytical techniques have become today of key interest in life science studies and have been rapidly growing in biology and medicine. ${ }^{4-12}$ Imaging mass spectrometry of trace metals is of increasing interest in different research fields where 
trace metals are involved such as physiology, pathophysiology and anatomy, development of metal-containing drugs, environmental toxicology, ex vivo calibration of molecular imaging techniques and others. ${ }^{12-15}$ Recently, Cooks and co-workers ${ }^{16}$ described the application of desorption electrospray ionization imaging mass spectrometry (DESI-MS/MS) for direct investigation of rat spinal cord tissue samples to identify specific biological compounds such as lipids within grey and white matter. The authors directly correlated ion images of specific lipids and fatty acids (e.g., deprotonated form of oleic acid) with anatomic features of spinal cord tissue such as the partition into grey matter and white matter. They achieved a lateral resolution of $200 \mu \mathrm{m}$. Yost and co-workers ${ }^{17}$ employed a hybrid linear ion trap/Orbitrap mass spectrometer to perform lipid imaging within rat spinal cord by tandem mass spectrometry (MS/MS) at an improved lateral resolution of $100 \mu \mathrm{m}$. The resulting ion images of biomolecules obtained by DESI-MS/MS ${ }^{16}$ and MALDILTQ/Orbitrap mass spectrometers ${ }^{17}$ can help to better understand lipid biochemistry.

The content and the distribution of essential and toxic metals in spinal cord is, so far, widely unknown. In 1978 Kurlander and Patten ${ }^{18}$ evaluated the role of toxic metals (especially of lead) in causing motor neuron disease (MND) and observed increased levels of metals in tissues or fluids taken from patients with MND. The role of earth alkali metal cations $\left(\mathrm{Mg}^{2+}, \mathrm{Ba}^{2+}\right.$ and $\left.\mathrm{Sr}^{2+}\right)$ and the transition metals $\left(\mathrm{Mn}^{2+}, \mathrm{Co}^{2+}\right.$ and $\left.\mathrm{Ni}^{2+}\right)$ in selective depression of synaptic transmission in spinal cord was studied by Ault and co-workers in $1980 .{ }^{19} \mathrm{Cu}$ is known as an important cofactor in several enzymatic processes crucial in the function of the central nervous system, including cytochrome- $c$ oxidase, copper-zinc superoxide dismutase, and dopamine $\beta$-hydroxylase. ${ }^{20}$ Mutations in copper/ zinc superoxide dismutase (SOD1) cause a subset of cases of autosomal dominant familial amyotrophic lateral sclerosis (FALS) e.g. reviewed by Andersen ${ }^{21}$ and as described by Ferrante et al. ${ }^{22}$ The authors found an increased 3-nitrotyrosine and oxidative damage in mice transgenic for a particular human $\mathrm{Cu} / \mathrm{Zn}$ superoxide dismutase mutation, causing a gain of function. Increased protein nitrosylation and oxidative stress are a common feature of neurodegenerative affections. Recently, some of us investigated the neuroprotective function of cellular prion protein in a mouse model of SOD1 linked amyotrophic lateral sclerosis which was characterized by rapid degeneration of motor neurons in spinal cord. ${ }^{3}$

Due to the small sample size $\left(2-5 \mathrm{~mm}^{2}\right)$ investigation of the metal distribution in mouse spinal cord requires powerful quantitative imaging techniques with higher spatial resolution than required for brain. Laser ablation inductively coupled plasma mass spectrometry (LA-ICP-MS) as elemental mass spectrometry has been established for bioimaging of trace metals, especially for the essential transition metals $\mathrm{Fe}, \mathrm{Cu}$, $\mathrm{Zn}$, and of selected non-metals (such as $\mathrm{C}, \mathrm{P}$ and $\mathrm{S}$ ) in our BrainMet (Bioimaging of Metals in Brain and Metallomics) laboratory at Forschungszentrum Jülich. By LA-ICP-MS we have systematically investigated metal distributions in brain using human and rodent samples under physiological and pathological conditions. $^{6,14,15,23,24}$

The aim of this study was to provide BrainMet techniques for bioimaging of metals and non-metals in mouse spinal cord, fully developed for routine application and to determine the micro-local metalloarchitecture in healthy tissue.

\section{Experimental}

\section{Instrumental and imaging of tissue}

For LA-ICP-MS a commercial laser ablation system introduced to the market in 2010 using a solid-state $\mathrm{Nd}$ :YAG laser (NWR 213 from New Wave Research, Fremont, CA, working at a wavelength of $213 \mathrm{~nm}$ ) was coupled directly via a connection tube to the ICP torch of a quadrupole-based inductively coupled plasma mass spectrometer (ICP-QMS) with collision cell (XSeries 2, Thermo Fisher Scientific, Bremen). The advantages of the new LA system are the large laser ablation chamber $(10 \mathrm{~cm} \times 10 \mathrm{~cm})$ suitable for investigation of large tissue sections or the placement of several conventional $76 \mathrm{~mm} \times 26 \mathrm{~mm}$ glass slides at once and a significant enhancement of sensitivity at smaller spot size and improved beam geometry. Mass spectrometric measurements by LA-ICP-MS for two-dimensional (2D) imaging of biological tissue were performed by line scanning ablation (line by line) with a focused laser beam under the optimized experimental parameters given in Table 1. A pixel

Table 1 Optimized experimental parameters of LA-ICP-MS imaging

\begin{tabular}{ll}
\hline ICP-QMS XSeries 2 & (Thermo Scientific) \\
Rf power & $1500 \mathrm{~W}$ \\
Carrier argon gas flow rate & $0.86 \mathrm{~mL} \mathrm{~min}$ \\
Sweeping/reading & 1 \\
Sampler/skimmer cone & Nickel \\
Acquisition mode & Time-resolved analysis \\
Dwell time & $50 \mathrm{~ms}$ \\
Number of isotopes $(\mathrm{m} / z)$ measured & 26 \\
Isotopes measured & ${ }^{13} \mathrm{C},{ }^{23} \mathrm{Na},{ }^{24} \mathrm{Mg},{ }^{25} \mathrm{Mg},{ }^{29} \mathrm{Si},{ }^{30} \mathrm{Si},{ }^{31} \mathrm{P},{ }^{33} \mathrm{~S},{ }^{34} \mathrm{~S},{ }^{35} \mathrm{Cl},{ }^{37} \mathrm{Cl},{ }^{39} \mathrm{~K},{ }^{47} \mathrm{Ti}$, \\
& ${ }^{48} \mathrm{Ti},{ }^{49} \mathrm{Ti},{ }^{54} \mathrm{Fe},{ }^{55} \mathrm{Mn},{ }^{56} \mathrm{Fe},{ }^{87} \mathrm{Fe},{ }^{63} \mathrm{Cu},{ }^{64} \mathrm{Zn},{ }^{65} \mathrm{Cu},{ }^{86} \mathrm{Zn},{ }^{87} \mathrm{Sr},{ }^{88} \mathrm{Sr}$ \\
Laser ablation system $N W R 213$ & $(\mathrm{New}$ Wave Research) \\
Wavelength of Nd:YAG laser & $213 \mathrm{~nm}$ \\
Laser pulse energy & $0.05 \mathrm{~mJ}$ \\
Ablation mode & $\mathrm{Scanning}($ line per line) \\
Repetition frequency & $20 \mathrm{~Hz}$ \\
Scan speed & $50 \mu \mathrm{m} \mathrm{s}{ }^{-1}$ \\
Laser spot size & $60 \mu \mathrm{m}$ \\
Distance between lines & $5 \mu \mathrm{m}$
\end{tabular}


dimension of $66 \mu \mathrm{m} \times 65 \mu \mathrm{m}$ could be realized, acquisition of one pixel necessitated $1.3 \mathrm{~s}$ and of one measurement $75 \mathrm{~min}$. Optical microscopic inspection of ablated tissue evidenced bars of partial residual tissue of $7 \mu \mathrm{m}$ between totally ablated lines of $58 \mu \mathrm{m}$.

For exemplification the section shown in Fig. 2A and B was of the dimension $3.1 \times 1.8 \mathrm{~mm}^{2}$ and measured with a field of view of $5.7 \times 2.5 \mathrm{~mm}^{2}$.

From the continuous list of raw pixel values elemental images were reconstructed using the IMAGENA ${ }^{\circledR}$ LA-ICP-MS Image Generation software created at Forschungszentrum Jülich. ${ }^{25}$ Metal concentrations were calculated from ion intensities averaged throughout freely drawn regions of interest (ROIs) within ion intensity images using PMOD version 3.0 (www.pmod.com).

Quantification of analytical data was performed using matrixmatched laboratory standards as demonstrated in several previous papers. Briefly, a set of matrix-matched homogenized laboratory standards with well-defined metal concentrations (e.g. containing 0; 3.8; 7.8; $11.9 ; 16.0$ and $19.8 \mu \mathrm{g} \mathrm{g}^{-1}$ added $\mathrm{Fe}$, respectively) was prepared. Homogenized laboratory standards were frozen and cut into $30 \mu \mathrm{m}$ sections by a cryostat microtome, and mounted onto glass slides. The set of lab standards and the tissue were analysed together under the same experimental conditions by LA-ICP-MS imaging in routine mode in the BrainMet laboratory as described elsewhere. ${ }^{15,24}$ In order to correct the variable slice thickness ion intensities were normalized to the net ${ }^{13} \mathrm{C}$-intensity averaged across the sample and the standard measurement, respectively, as a substitute of the average layer thickness. In a previous series of 11 neighbouring brain sections this correction had allowed to reduce the coefficients of variation for the concentrations of $\mathrm{Fe}$, $\mathrm{Cu}, \mathrm{Zn}$ and $\mathrm{Mn}$ from 29, 24, 30 and 27\% to 12, 13, 12 and 17\%, respectively, in a defined area of $2 \mathrm{~mm}^{2}$.

The regression coefficients of the calibration curves measured by LA-ICP-MS were better than 0.99 for $\mathrm{Fe}, \mathrm{Zn}$ and $\mathrm{Cu}$ and better than 0.95 for $\mathrm{Mn}$ and $\mathrm{Rb}$. The final metal concentrations in the prepared laboratory standards were verified by ICP-MS after microwave-induced digestion and their homogeneity was investigated using LA-ICP-MS imaging.

\section{Samples}

All animal experiments were approved by the local authorities and in accordance with current guidelines. 12 week old male wild type C57/B16 mice were killed by decapitation. Immediately skin and the dorsal musculature were removed and the spinal cords extracted from the vertebral channel using microsurgical forceps and partitioned into 3 segments. The segments were frozen in $-50{ }^{\circ} \mathrm{C}$ cold isopentane, allowed to dry and stored at $80{ }^{\circ} \mathrm{C}$. $40 \mu \mathrm{m}$ thick coronal cryosections were prepared on a Leica CM 3500. Some neighbouring sections of $20 \mu \mathrm{m}$ were obtained for hematoxylin eosine staining (cf. Fig. 1).

\section{Results and discussion}

The analytical workflow from sample preparation by cryocutting of mouse spinal cord via the LA-ICP-MS bioimaging procedure, where the sample is scanned (line by line) by a focused laser beam and ion intensities of analytes of interest are measured, up to a final evaluation of the data using the LA-ICP-MS Image Generation software written in house yielding quantitative images

\section{Sample preparation}

- Dissection of the spinal cord

- Cryocutting of $40 \mu \mathrm{m}$ slices
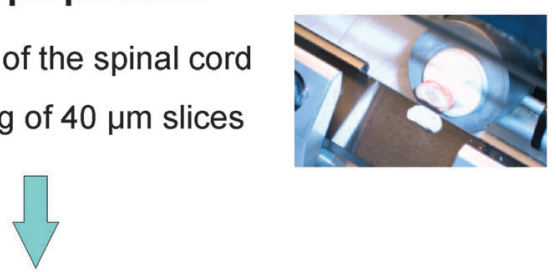

\section{LA-ICP-MS measurement}

- Line-by-line ablation of samples and standards

- Data acquisition, preselected $\mathrm{m} / \mathrm{z}$<smiles>C1CC2CC3CC(C3)C(C1)C2</smiles>

\section{Data Analysis \\ - Quantification using matrix matched laboratory standards}

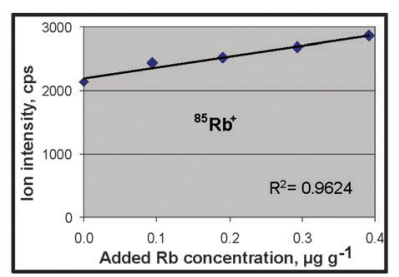

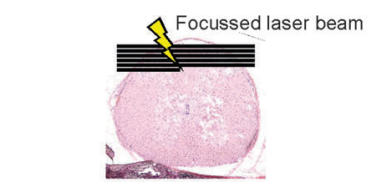

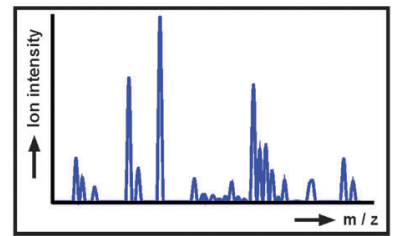

\section{- Image reconstruction using IMAGENA ${ }^{\circledR}$ and calibration}

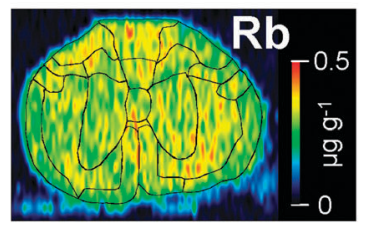

Fig. 1 Experimental workflow of bioimaging of elements in a mouse spinal cord section leading to a quantitative image exemplified for $\mathrm{Rb}$.

of metals is summarized in Fig. 1 and has been further described elsewhere by Becker et al. ${ }^{8,24}$ Images of the transition metals Fe, $\mathrm{Cu}, \mathrm{Zn}$ and $\mathrm{Mn}$, the earth alkali and alkali metals $\mathrm{Mg}, \mathrm{Na}, \mathrm{K}$ ( $\mathrm{Rb}$ is shown in Fig. 1) and also of the non-metals $\mathrm{C}, \mathrm{P}, \mathrm{S}$ and $\mathrm{Cl}$ are summarized in Fig. 2. For comparison and anatomical orientation a photomicrograph of a native section before laser ablation and images of analogue sections from the WatsonPaxinos-Kayalioglu-Heise mouse spinal cord atlas are given. ${ }^{26}$ A set of regions of interest defined upon the mutual information provided by the maps of $\mathrm{Fe}, \mathrm{Cu}, \mathrm{Zn}, \mathrm{Mn}, \mathrm{C}$ and $\mathrm{P}$ is delineated onto each map. The most salient morphological feature was the grey matter/white matter partition in line with former brain studies using LA-ICP-MS imaging where metals are enriched in grey matter. ${ }^{6,14,23,24}$

Average regional concentrations are detailed in Table 2. Spinal grey and white matter concentrations were 8 and $4 \mu \mathrm{g} \mathrm{g}^{-1}$ of $\mathrm{Fe}, 3$ and $2 \mu \mathrm{g} \mathrm{g}^{-1}$ of $\mathrm{Cu}, 8$ and $5 \mu \mathrm{g} \mathrm{g}^{-1}$ of $\mathrm{Zn}$, 0.4 and $0.17 \mu \mathrm{g} \mathrm{g}^{-1}$ of $\mathrm{Mn}$, respectively. These values were obtained from the three samples measured, the concentrations of which deviated by $6 \%, 5 \%, 8 \%$ and $10 \%$ for $\mathrm{Fe}, \mathrm{Cu}$, $\mathrm{Zn}$ and $\mathrm{Mn}$, respectively. Except for $\mathrm{Fe}$, white matter 

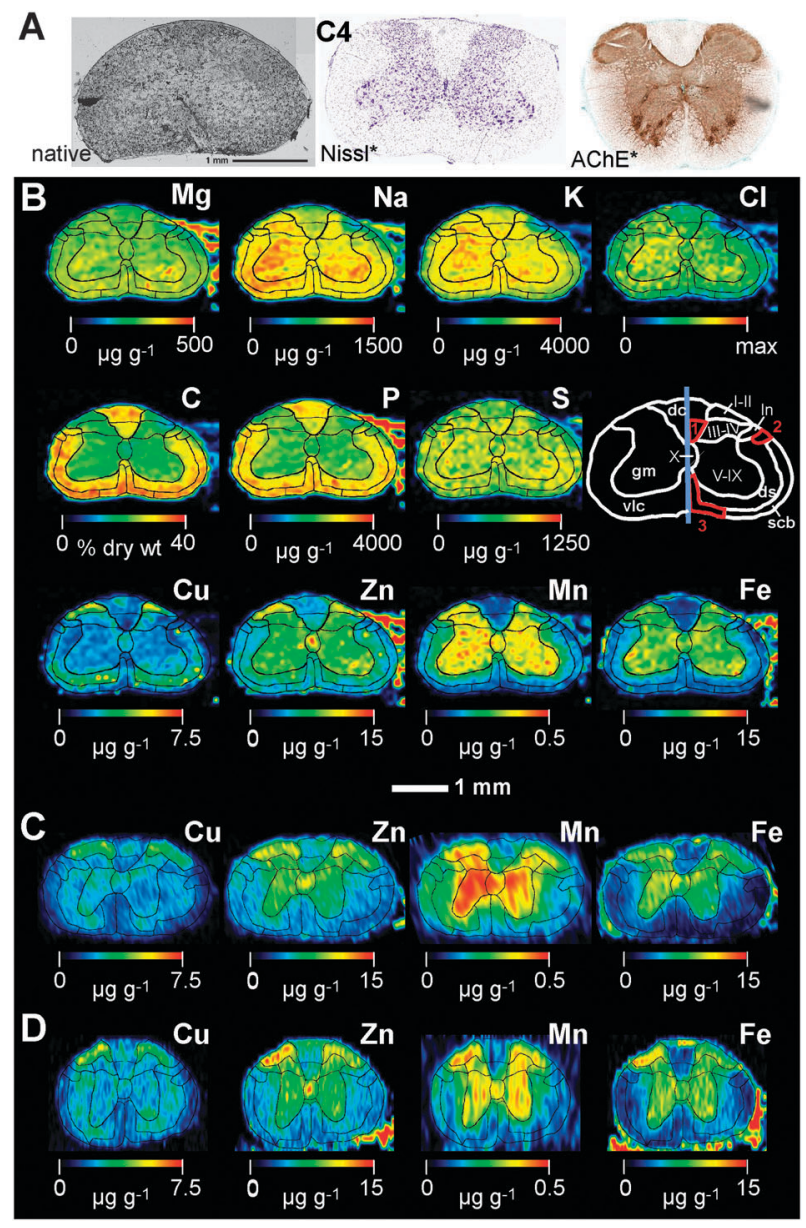

Fig. 2 Element concentration maps of mouse spinal cord: (A) photomicrograph of a neighbouring section before laser ablation and $\left({ }^{*}\right)$ pictures adapted from the Watson-Paxinos-Kayalioglu-Heise atlas ${ }^{26}$ for spatial orientation. (B) Images of the transition metals $\mathrm{Cu}, \mathrm{Zn}, \mathrm{Mn}$ and $\mathrm{Fe}$, the earth alkali and alkali metals $\mathrm{Mg}, \mathrm{Na}, \mathrm{K}$, and the non-metals $\mathrm{C}, \mathrm{P}$ and $\mathrm{S}$ in a mouse spinal cord section obtained by LA-ICP-MS imaging. Onto each map are overlaid the contours of the set of anatomical regions of interest used for the readout of concentrations given in Table 2. The respective labels are given in the white sketch in the right column. Abbreviations: 1, dorsal corticospinal tract; 2, rubrospinal tract; 3, antero-medial tract; I-X; numbers of Rexed laminae of gm; dc, dorsal column; ds, deep segment of vlc; gm, grey matter; ln, lateral nucleus; scb, spinocerebellar and spinothalamic tract; vlc, ventro-lateral column; AChE, acetylcholinesterase staining; Nissl, Nissl staining. (C) and (D) Analogous images of $\mathrm{Fe}, \mathrm{Cu}, \mathrm{Zn}$ and $\mathrm{Mn}$ of sections from a second and a third animal underlining the biological uniformity of spinal element distribution and its technical reproducibility.

concentrations were in agreement with those measured in a previous study ${ }^{27}$ in the cerebral white matter (corpus callosum, 8, 2, 7 and $0.16 \mu \mathrm{g} \mathrm{g}^{-1}$ of $\mathrm{Fe}, \mathrm{Cu}, \mathrm{Zn}$ and $\mathrm{Mn}$, respectively, in $n=$ 11 replicates) in mice. Also $\mathrm{Fe}$ and $\mathrm{Zn}$ concentrations were comparable in the cerebral cortex $\left(8\right.$ and $\left.9 \mu \mathrm{g} \mathrm{g}^{-1}\right)$ and spinal grey matter, whereas $\mathrm{Cu}$ and $\mathrm{Mn}$ were lower concentrated in the cortex $\left(1.9\right.$ and $\left.0.15 \mu \mathrm{g} \mathrm{g}^{-1}\right)$. Interestingly, there was no enrichment of $\mathrm{Cu}$ around the central channel, a phenomenon systematically observed around inner cerebral ventricular spaces. This is in line with the absence and presence of plexus choroidei in the spinal cord and the brain respectively. Further structural details
Table 2 Regional average element concentrations

\begin{tabular}{|c|c|c|c|c|}
\hline & \multicolumn{3}{|c|}{$\mu \mathrm{g} \mathrm{g}^{-1}$} & \multirow{2}{*}{$\begin{array}{l}\% \text { Dry } \\
\text { organic } \\
\text { matter }(C)\end{array}$} \\
\hline & $\mathrm{Mn}$ & $\mathrm{Fe} \mathrm{Cu} \mathrm{Zn}$ & $\mathrm{Rb}$ & \\
\hline Grey matter total & 0.4 & 8.32 .97 .8 & 0.3 & 21 \\
\hline White matter total & 0.2 & $\begin{array}{lll}3.9 & 2.0 & 4.8\end{array}$ & 0.3 & $30^{a}$ \\
\hline \multicolumn{5}{|l|}{ Grey matter subregions } \\
\hline Laminae I and II & 0.3 & 8.43 .79 .4 & 0.3 & 21 \\
\hline Laminae III and IV & 0.3 & $\begin{array}{lll}7.8 & 2.3 & 7.7\end{array}$ & 0.3 & 22 \\
\hline Laminae V-IX & 0.4 & 8.52 .27 .3 & 0.3 & 20 \\
\hline Lamina X & 0.4 & $8.3 \quad 2.4 \quad 9.0$ & 0.3 & 20 \\
\hline Lateral nucleus & 0.2 & $\begin{array}{lll}4.9 & 1.9 & 5.4\end{array}$ & 0.3 & 29 \\
\hline \multicolumn{5}{|l|}{ White matter afferent tracts } \\
\hline Dorsal column & 0.2 & $3.92 .0 \quad 5.5$ & 0.3 & 32 \\
\hline Ventrolateral column (vlc) & 0.2 & 3.92 .04 .6 & 0.3 & 30 \\
\hline Vlc deep segment & 0.2 & $4.2 \quad 2.4 \quad 5.0$ & 0.3 & 30 \\
\hline $\begin{array}{l}\text { Spinocerebellar/-thalamic tract } \\
\text { White matter motor tracts }\end{array}$ & 0.1 & $\begin{array}{lll}3.3 & 1.6 & 4.2\end{array}$ & 0.3 & 30 \\
\hline Anteromedial corticospinal & 0.2 & $3.41 .7 \quad 4.3$ & 0.3 & 30 \\
\hline Dorsal corticospinal & 0.2 & $\begin{array}{lll}3.8 & 1.9 & 5.5\end{array}$ & 0.3 & 29 \\
\hline Rubrospinal & 0.1 & $2.8 \quad 1.7 \quad 4.3$ & 0.3 & 30 \\
\hline Connective tissue and blood plexus & 0.1 & $10.7 \quad 0.6 \quad 6.4$ & 0.1 & 9 \\
\hline
\end{tabular}

resolved were an enrichment of $\mathrm{Zn}$ and $\mathrm{Cu}$, in the laminae $\mathrm{I}$ and II, in line with the high synaptic and cellular density there, an enrichment of $\mathrm{Zn}$ in the central grey reaching $14 \mu \mathrm{g} \mathrm{g}^{-1}$, and comparatively high $\mathrm{Cu}$ in the deep segments of the ventrolateral column. In the brain in contrast, we consistently observed lowest $\mathrm{Cu}$ concentrations in all white matter areas. The carbon concentration in white matter exceeded that of grey matter by a factor of 1.44 .

It is interesting to note, we could detect, map and quantify rubidium for the first time using LA-ICP-MS bio-imaging. The distribution pattern was perfectly congruent to that of $\mathrm{K}$ as could be expected from partially similar biochemical behaviour-e.g. $\mathrm{Rb}^{+}$is a substrate of trans-membrane $\mathrm{K}^{+}$ channels. The concentrations of $0.3 \mu \mathrm{g} \mathrm{g}^{-1}$ measured here undercut literature values of $3 \mu \mathrm{g} \mathrm{g}^{-1}$ reported in mouse brain homogenates ${ }^{28}$ also because the brain contains substructures of high $\mathrm{Rb}$ content. In human brain regional $\mathrm{Rb}$ concentrations between 1.5 and $2.7 \mu \mathrm{g} \mathrm{g}^{-1}$ were reported. ${ }^{29}$

Future applications of the analytical imaging techniques developed here will be extended on diseased tissue such as amyotrophic lateral sclerosis or motor neuron disease. There, altered oxidative metabolism and metal turnover, as described, suggest a special interest in metal distributions.

\section{Conclusions}

Mass spectrometry imaging using LA-ICP-MS of biometals is suitable for quantitatively studying metal distribution in mouse cervical spinal cord. Using a new commercially available laser ablation system the spatial resolution of imaging studies could be improved to $65 \mu \mathrm{m}$ spatial resolution.

\section{Acknowledgements}

The authors thank Astrid Zimmermann (Forschungszentrum Jülich) for technical support, Thermo Scientific, Bremen, Germany for instrumental support of BrainMet laboratory 
at Research Centre Juelich and R. Hutchinson and C. O'Connor (New Wave Research Division, ESI, Huntington, UK) for experimental support of these first LA-ICP-MS imaging experiments with the new laser ablation system NWR 213, and Evamarie Görz for technical support. MO and PS were supported by EU projects (Nadine, NeuroTAS, cNeupro). Bei $\mathrm{Wu}$ is much grateful for the support of this work by the Alexander von Humboldt Foundation.

\section{References}

1 R. A. Linker, P. Brechlin, S. Jesse, P. Steinacker, D. H. Lee, A. R. Asif, O. Jahn, H. Tumani, R. Gold and M. Otto, Proteome Profiling in Murine Models of Multiple Sclerosis: Identification of Stage Specific Markers and Culprits for Tissue Damage, PLoS One, 2009, 4, e7624.

2 R. A. Linker, M. Maurer, S. Gaupp, R. Martini, B. Holtmann, R. Giess, P. Rieckmann, H. Lassmann, K. V. Toyka, M. Sendtner and R. Gold, CNTF is a major protective factor in demyelinating CNS disease: a neurotrophic cytokine as modulator in neuroinflammation, Nat. Med., 2002, 8, 620-624.

3 P. Steinacker, A. Hawlik, S. Lehnert, O. Jahn, S. Meier, E. Gorz, K. E. Braunstein, M. Krzovska, B. Schwalenstocker, S. Jesse, C. Propper, T. Bockers, A. Ludolph and M. Otto, Neuroprotective Function of Cellular Prion Protein in a Mouse Model of Amyotrophic Lateral Sclerosis, Am. J. Pathol., 2010, 176, 1409-1420.

4 A. Carmona, P. Cloetens, G. Deves, S. Bohic and R. Ortega, Nano-imaging of trace metals by synchrotron X-ray fluorescence into dopaminergic single cells and neurite-like processes, J. Anal. At. Spectrom., 2008, 23, 1083-1088.

5 S. S. Rubakhin and J. V. e. Sweedler, Mass Spectrometric Imaging: Principles and Protocols, Springer, Heidelberg, 2010, vol. 656.

6 J. S. Becker, A. Matusch, C. Palm, D. Salber, K. A. Morton and J. Su. Becker, Bioimaging of metals in brain tissue by laser ablation inductively coupled plasma mass spectrometry (LA-ICP-MS) and metallomics, Metallomics, 2010, 2, 104-111.

7 M. Stoeckli, P. Chaurand, D. E. Hallahan and R. M. Caprioli, Imaging mass spectrometry: a new technology for the analysis of protein expression in mammalian tissues, Nat. Med., 2001, 7, 493-496.

8 J. S. Becker, Bioimaging of metals in brain tissue from micrometre to nanometre scale by laser ablation inductively coupled plasma mass spectrometry: state of the art and perspectives, Int. J. Mass Spectrom., 2010, 289, 65-75.

9 R. M. A. Heeren, in Encyclopedia of spectroscopy and spectrometry, ed. J. Lindon, G. Tranter and D. Koppenaal, Elsevier, Amsterdam, 2010, p. 1443.

10 D. S. Cornett, S. L. Frappier and R. M. Caprioli, MALDI-FTICR imaging mass spectrometry of drugs and metabolites in tissue, Anal. Chem., 2008, 80, 5648-5653.

11 J. A. McLean, W. B. Ridenour and R. M. Caprioli, Profiling and imaging of tissues by imaging ion mobility-mass spectrometry, J. Mass Spectrom., 2007, 42, 1099-1105.

12 A. Brunelle, D. Touboul and O. Laprevote, Biological tissue imaging with time-of-flight secondary ion mass spectrometry and cluster ion sources, J. Mass Spectrom., 2005, 40, 985-999.

13 J. S. Becker, A. Matusch, J. Su. Becker, B. Wu, C. Palm, A. J. Becker and D. Salber, Mass spectrometric imaging (MSI) of metals using advanced BrainMet techniques for biomedical research, Int. J. Mass Spectrom., 2011, 307, 3-15.
14 J. S. Becker, M. Zoriy, A. Matusch, B. Wu, D. Salber and C. Palm, Bioimaging of metals by laser ablation inductively coupled plasma mass spectrometry (LA-ICP-MS), Mass Spectrom. Rev., 2010, 29, $156-175$.

15 J. S. Becker, M. V. Zoriy, C. Pickhardt, N. Palomero-Gallagher and K. Zilles, Imaging of copper, zinc, and other elements in thin section of human brain samples (hippocampus) by laser ablation inductively coupled plasma mass spectrometry, Anal. Chem., 2005, 77, 3208-3216.

16 M. Girod, Y. Shi, J. X. Cheng and R. G. Cooks, Desorption electrospray ionization imagingmass spectrometry of lipids in rat spinal cord, J. Am. Soc. Mass Spectrom., 2010, 21, 1177-1189.

17 R. R. Landgraf, M. C. P. Conaway, T. J. Garrett, P. W. Stacpoole and R. A. Yost, Imaging of Lipids in Spinal Cord Using Intermediate Pressure Matrix-Assisted Laser Desorption-Linear Ion Trap/Orbitrap MS, Anal. Chem., 2009, 81, 8488-8495.

18 H. M. Kurlander and B. M. Patten, Metals in spinal cord tissue of patients dying of motor neuron disease, Ann. Neurol., 1979, 6, 21-24.

19 B. Ault, R. H. Evans, A. A. Francis, D. J. Oakes and J. C. Watkins, Selective depression of excitatory amino acid induced depolarizations by magnesium ions in isolated spinal cord preparations, J. Physiol., 1980, 307, 413-428.

20 B. P. Goodman, B. W. Chong, A. C. Patel, G. P. Fletcher and B. E. Smith, Copper deficiency myeloneuropathy resembling B12 deficiency: partial resolution of MR imaging findings with copper supplementation, Am. J. Neuroradiol., 2006, 27, 2112-2114.

21 P. M. Andersen, Amyotrophic lateral sclerosis associated with mutations in the $\mathrm{CuZn}$ superoxide dismutase gene, Curr. Neurol. Neurosci. Rep., 2006, 6, 37-46.

22 R. J. Ferrante, L. A. Shinobu, J. B. Schulz, R. T. Matthews, C. E. Thomas, N. W. Kowall, M. E. Gurney and M. F. Beal, Increased 3-nitrotyrosine and oxidative damage in mice with a human copper/zinc superoxide dismutase mutation, Ann. Neurol., 1997, 42, 326-334.

23 M. Zoriy, M. Dehnhardt, A. Matusch and J. S. Becker, Comparative imaging of $\mathrm{P}, \mathrm{S}, \mathrm{Fe}, \mathrm{Cu}, \mathrm{Zn}$ and $\mathrm{C}$ in thin sections of rat brain tumor as well as control tissues by laser ablation inductively coupled plasma mass spectrometry, Spectrochim. Acta, Part B, 2008, 63, 375-382.

24 A. Matusch, C. Depboylu, C. Palm, B. Wu, G. U. Hoglinger, M. K. Schafer and J. S. Becker, Cerebral bioimaging of $\mathrm{Cu}, \mathrm{Fe}, \mathrm{Zn}$, and $\mathrm{Mn}$ in the MPTP mouse model of Parkinson's disease using laser ablation inductively coupled plasma mass spectrometry (LA-ICP-MS), J. Am. Soc. Mass Spectrom., 2010, 21, 161-171.

25 T. Osterholt, D. Salber, A. Matusch, J. S. Becker and C. Palm, IMAGENA: Image Generation and Analysis - an interactive software tool handling LA-ICP-MS data, Int. J. Mass Spectrom., 2011, 307, 232-239.

26 C. Watson, G. Paxinos, G. Kayalioglu and C. Heise, The spinal cord, Academic Press, London-Burlington-San Diego, 2009, p. 308.

27 A. Matusch, L. S. Fenn, C. Depboylu, M. Klietz, S. Strohmer, J. A. McLean and J. S. Becker, Combined elemental and biomolecular mass spectrometry imaging (MSI) for probing the inventory of tissue at a micrometer scale, submitted.

28 S. Takahashi, I. Takahashi, H. Sato, Y. Kubota, S. Yoshida and Y. Muramatsu, Age-related changes in the concentrations of major and trace elements in the brain of rats and mice, Biol. Trace Elem. Res., 2001, 80, 145-158.

29 C. Belavari, E. Andrasi, Z. Molnar and D. Gawlik, Determination of $\mathrm{Na}, \mathrm{K}, \mathrm{Rb}$ and $\mathrm{Cs}$ distribution in human brain using neutron activation analysis, Microchim. Acta, 2004, 146, 187-191. 